\title{
APRESENTAÇÃO
}

\section{$\underline{\text { Sobre diálogos e interconexões }}$}

Já houve quem tentasse colocar tudo na "raça". Numa mistura de ciência e uma espécie de obsessão - pela negação muitas vezes. Foi por aí que se urdiu uma reflexão candente sobre o destino da nação nas últimas décadas do século XIX até os alvissareiros anos 1930. Falava-se amiúde em "raça" para destacar a sua não importância, enquanto espectro que rondava a comunidade nacional, constituindo preocupação cardinal do pensamento social brasileiro. De Francisco Adolfo de Varnhagen, Silvio Romero, Oliveira Lima, passando por Nina Rodrigues, Euclides da Cunha, Oliveira Viana e Paulo Prado,assim caminhamos.

Nota-se um consenso na historiografia brasileira de que a "questão racial" mobilizou uma gama multifacetada de agencies: desde teóricos, políticos, gestores públicos, juristas, médicos sanitaristas, jornalistas e ensaístas da geração dos "intérpretes do Brasil" (Capistrano de Abreu, Gilberto Freyre, Sérgio Buarque de Holanda e Caio Prado Júnior) até os especialistas da chamada "Escola Paulista de Sociologia" (Florestan Fernandes, Fernando Henrique Cardoso e Octavio Ianni), que no pós-guerra desenvolveram o projeto UNESCO de estudos sobre as relações raciais. Ainda assim atravessamos boa parte do século XX com um Brasil republicano arrastando a memória do cativeiro para um distante "passadoesquecimento", por assim dizer. O pós-emancipação sequer virava capítulo derradeiro dos estudos sobre Abolição. As pesquisas sobre as "relações raciais" foram de fundamental importância para se compreender as desigualdades e assimetrias entre negros e brancos na sociedade brasileira, é bom destacar, porém acabaram por encapsular o campo do pós-abolição das narrativas históricas. Vários processosurbanização, industrialização, modernidade, mundos do trabalho, questão agrária, relações de gênero, culturas políticas, cidadania, eleições etc. - foram desidratados da dimensão mais ampla desse campo, com seus legados e principais sujeitos.

Diante de tal panorama, inscrever a "questão racial" às múltiplas experiências históricas da sociedade brasileira e não vê-la 
confinada aos temas da escravidão virou - em certa medida - um projeto político do tempo presente, que tem a sua maior aposta a lei 10.639.Não há porque negar o avanço democrático do processo atual, saudá-lo e reconhecer o seu próprio percurso de debates e embates, dentro e fora das universidades. Investimento importante seria identificar como foram gerados "silêncios" sobre a "questão racial" para vários temas-eventos da história do Brasil. Podemos citar, por exemplo, as atmosferas de disputassimbólicas - imagens e representações - em torno da "independência" no Brasil. Na década de 1970, Maria Odila já chamava a atenção para o fator "medo" e o "haitianismo" na arena das expectativas sobre a separação política e a participação popular nas ruas da Corte, por um lado. E autoridades despejando socos e pontapés em comícios que escondiam xenofobias, por outro. Os estudos clássicos já mostraram que muitas das "questões raciais" - travestidas de outras linguagens, nomenclaturas e significados - estavam presentes.

É fato que em determinadas paisagens historiográficas os cenários que envolveram personagens, contextos, movimentos e expectativas que cruzaram narrativas sobre "raça", racismo, nação, identidades e culturas sequer apareceram emoldurados nas retóricas iconoclastas. Inclui-los hoje na agenda de pesquisa pode ser mais do que tão somente um "resgate" historiográfico. Sugerem novas pautas, revisões, polifonias e multivocalidades desafiadoras, nem sempre percebidas nos eventos-efemérides, nos roteiros analíticos e/ou nas políticas editoriais acadêmicas.

As temáticas da ditadura e da redemocratização vistas pela transversalidade da "raça", especialmente no decurso dos anos 1970 e 1980, podem seguir outros caminhos- nunca desvios -, considerando os sentidos político-culturais de vários atores e segmentos sociais, com suas estratégias, clivagens, aspirações e demandas por reconhecimento, direitos e liberdade de manifestação. Neste dossiê o ponto de partida foi exatamente a tentativa de estabelecer diálogos e interconexões entre as temáticas da ditadura e da redemocratização, de um lado, e a experiência negra, de outro, a fim de superar falsas dicotomias.

A temporalidade que organiza estas aproximações ou entrecruzamentos são os anos 1970 e 1980, sobretudo. Quem começa é George Reid Andrews ao surpreender o protagonismo político negro a partir de novas balizas, diretrizes e cronologias - embora por vezes 
cristalizadas - que antecederam o surgimento de organizações contemporâneas de luta antirracista (1978) até o pós-centenário da Abolição (1988). Tratou-se de um protagonismo ativo e entrelaçado à história nacional (e transnacional) no período da redemocratização. Nem sempre ideias e ações político-partidárias foram orquestradas. Sons repercutiam e ganhavam ritmos que assustaram mesmo ouvidos insuspeitos. Paulina Alberto acompanha a efervescência do Black Rio e dos bailes de soul music, que contagiavam a juventude negra do subúrbio carioca e redesenhavam símbolos racializados - muitos dos quais transnacionais - em torno da identidade positivada, do estilo contestatório e da afirmação estética. Já conhecemos algo sobre tais experiências e repertórios para São Paulo, embora contextos urbanos diferenciados ainda precisem de mais investigações. Para uma parte da juventude negra dos anos 1970, o protesto político teve uma trilha sonora própria que os estudos temáticos ainda não se interessaram em ouvir. Linguagens, tramas e performances foram diversificadas e nem sempre apareceram textualizadas. A campanha contra o apartheid na África do Sul - e com ela a luta para que Nelson Mandela fosse libertado da prisão- converteu-se em ferramenta política nas mãos de ativistas negros que denunciavam a segregação racial, tanto do outro lado do Atlântico como no Brasil. Com Jerry Dávila conseguimos "ouvir" outros sons e vozes que embarcavam e desembarcavam nos litorais africanos: dos movimentos de independência em países como Guiné-Bissau, Angola e Moçambique, até chegar aos apelos para a libertação de Mandela e as homenagens a Steve Biko, líderes sulafricanos.

Vale destacar que a dimensão cultural - quase sempre crítica ou apropriada pelo viés político - foi um porta-voz nos debates e impasses dos anos de chumbo. Com poucos canais de expressão diante do arbítrio da ditadura, identidades, comportamentos, alteridades e taxinomias raciais ganharam laudas, palcos e telas. Noel Carvalho rouba a cena - melhor seria o set - ao abordar a trajetória do cineasta negro Odilon Lopes, desde os primeiros anos de atividade profissional na televisão até a realização do seu filme Um é роисo, dois é bom, de 1970. Enquanto isso Dmitri Fernandes examina a emergência da emblemática artista Clementina de Jesus - e tudo que ela representou sobre a cultura negra - nas décadas de 1970 e 1980. Sua "descoberta" (da "autêntica" sambista) se transformaria em metáfora para se investigar os sentidos de uma diáspora que foi 
articulada pelos movimentos de afirmação da "raiz afro-negra". Com Mário Augusto da Silva conhecemos o despontar da pulsante literatura negra na década de 1980, por meio de eventos, obras e debates que galvanizaram a atenção de intelectuais nacionais e estrangeiros.

Num artigo coletivo Sandra Martins, Togo Ioruba (Gerson Theodoro) e Flávio Gomes invadem os muros acadêmicos para encontrar uma juventude negra original que, a partir do início dos anos 1970 cria um movimento de reflexão (e reivindicação) sobre objetos/sujeitos da "raça" e do racismo na Universidade Federal Fluminense através do GTAR (Grupo de Trabalho André Rebouças), que teve a força viral de Beatriz Nascimento e o apoio luxuoso de Eduardo de Oliveira e Oliveira, intelectuais negros ícones daquela geração. Para encerrar o dossiê, Petrônio Domingues nos conduz a outras latitudes que interseccionam as relações entre redemocratização e "raça" no Brasil contemporâneo, na medida em que se vale de memórias, mitos e símbolos para reconstituir o processo de invenção de João Mulungu como herói negro. Revalorizado no imaginário das hostes antirracistas, esse líder quilombola vem fazendo a cabeça e tocando o coração de muitos negros que sonham com igualdade, ampliação de direitos e justiça.

Agradecemos aos colegas que colaboraram com o presente dossiê e possibilitaram ampliar os estudos e reflexões sobre Histórias do tempo presente: ditadura, redemocratização e raça no Brasil. Esta edição da revista ainda traz três artigos. Leyserée Xavier investiga a reforma religiosa promovida por Akhenaton, faraó egípcio da XVIII Dinastia, que, entre outras coisas, elevou Aton ao lugar de divindade suprema. Julio Bentivoglio, por sua vez, debruça-se sobre os textos publicados nos primeiros onzes anos da Revista do Instituto Histórico e Geográfico Brasileiro (IHGB), de 1839 a 1850, tendo em vista a mapear autores, temáticas, recortes temporais e geográficos, dentre outros aspectos que constituíam a escrita da história brasileira vinculada ao IHGB. Concluímos esse número com o artigo de Alessandro Batistella sobre o político paranaense Abilon de Souza Naves, principal liderança do Partido Trabalhista Brasileiro (PTB) na década de 1950.

Petrônio Domingues

Flávio Gomes

(Organizadores) 